Maciej GIS

\title{
Representativeness of emissions of toxic substances in bench tests reflecting the road traffic conditions of a vehicle
}

The results of measurements of exhaust emissions in real road traffic differ significantly from the results of stationary homologation tests. One of the solutions, helpful in determining the actual emission, is the creation of stationary exhaust emission tests simulating the use of the vehicle on the road. The article presents the method of reconstructing the synthetic driving test obtained on the basis of road tests and presents the obtained profile of the speed course. The authors discussed the reasonableness of selecting the emission component determining the correctness of the representativity of the stationary test obtained, which determines the amount of work done by the engine.

Key words: driving cycle, road tests, emission of toxic substances, chassis dynamometer, synthesis of road tests

\section{Introduction}

Research on the ecological properties of automotive combustion engines is carried out at almost every stage of the life cycle of vehicles. The research is carried out in the development phase of the engine concept (basic cognitive research), in the design phase (during prototype tests), in the production phase (during quality control), in the admission stage (approval tests) and in the operation phase (diagnostic tests). The purpose of all these tests is to determine the emission of pollutants in the engine's exhaust gas under given conditions. This goal is carried out in dynamometer tests in which different engine operation conditions are reproduced [3]. Due to the discrepancy of emissions in real traffic conditions with emissions resulting from stationary (eg homologation) tests, it seems reasonable to prepare test conditions imitating the real road conditions in the best way $[9,10]$.

\section{Explanation of the issue}

Research to date on the subject of representativeness of bench tests relative to road conditions needs to be clarified and explained. Simulating traffic conditions during stationary tests on a chassis dynamometer is a difficult task due to numerous random factors. Currently used chassis dynamometer tests are perfectly suited for comparative tests aimed at determining the emission values of particular exhaust components during strictly defined engine operating conditions. However, these are not tests that precisely represent real traffic conditions, but rather some kind of patterns for emission tests [6]. It would be necessary to create a bench test, which would be based on the measured operating parameters of the representative group of vehicles in real traffic and additionally introduce a random factor during the test construction. This factor, however, cannot lead to complete randomness of the test [1].

\section{Description of the measurements}

Taking into account the above assumptions, a series of measurements was carried out on a test vehicle on a designated measurement route. During the registration of vehicle performance parameters, the emission of toxic substances from its exhaust system was also measured using a PEMS mobile analyzer. The results of emission measurements were later used to verify the level of representativeness of the designed test.

\subsection{The object of research}

The test object was the Ford Focus Flexifuel sparkignition vehicle shown in Figure 1, produced in 2008. Technical data of the car can be found in Table 1.

Table 1. Technical data of the test car

\begin{tabular}{|l|c|}
\hline Name & Data \\
\hline Make & Ford \\
\hline Type & Focus \\
\hline Power & $92 \mathrm{~kW}$ \\
\hline Engine stroke volume & $1798 \mathrm{~cm}^{3}$ \\
\hline Location and number of cylinders & In-line, 4 \\
\hline Emission level & Euro 4 \\
\hline Transmission & $\begin{array}{c}\text { Manual (five forward gears, } \\
\text { one reverse gear) }\end{array}$ \\
\hline
\end{tabular}

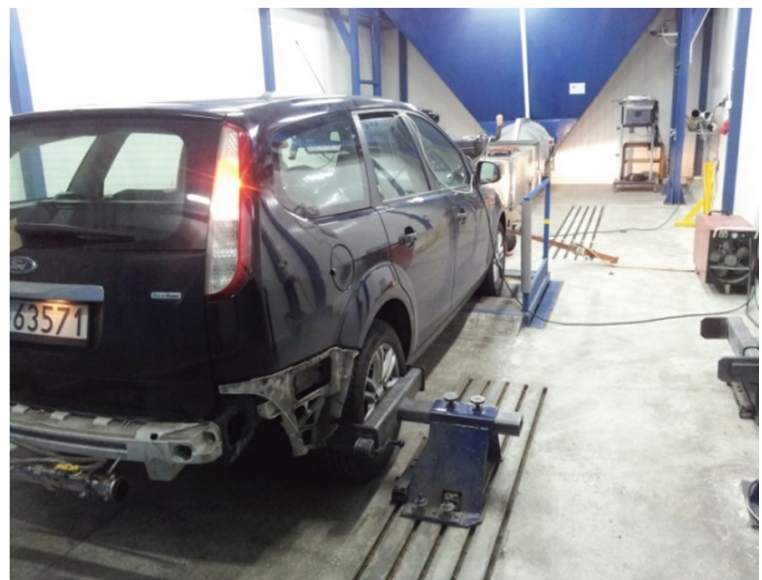

Fig. 1. Ford Focus car on the test bench

\subsection{Measuring equipment}

The benchmark emission tests were carried out on a 2roller chassis dynamometer 2PT220EX type, manufactured by Jaroš with two rollers with a diameter of $372 \mathrm{~mm}$, with electric simulation of motion resistance and mechanical simulation of inertia placed in the low temperature chamber. This dynamometer allows the examination of vehicles (also at ambient temperature up to $-14^{\circ} \mathrm{C}$ ) with the following parameters:

- maximum net power on wheels up to $220 \mathrm{~kW}$,

- maximum speed of $130 / 200 \mathrm{~km} / \mathrm{h}$, 
- pressure on the drive axle up to $2400 \mathrm{~kg}$,

- drive for one axle or more than one axis with the possibility of disconnecting the drive,

- maximum wheelbase of the drive axle: $2100 \mathrm{~mm}$,

- maximum vehicle height $2900 \mathrm{~mm}$, maximum distance of the rear drive axle from the front of the car $5000 \mathrm{~mm}$. Emission measurements were made using a set of AMA

i60 AVL analyzers. The following pollutants were measured:

- carbon monoxide (low concentrations) $\left(\mathrm{CO}_{\text {low }}\right)$,

- carbon monoxide (high concentrations) $\left(\mathrm{CO}_{\text {high }}\right)$,

- carbon dioxide $\left(\mathrm{CO}_{2}\right)$,

- hydrocarbon totals (THC),

- methane $\left(\mathrm{CH}_{4}\right)$,

- nitrogen oxides $\left(\mathrm{NO}_{\mathrm{x}}\right)$, nitric oxide (NO) and nitrogen dioxide $\left(\mathrm{NO}_{2}\right)$, nitrous oxide $\left(\mathrm{N}_{2} \mathrm{O}\right)$.

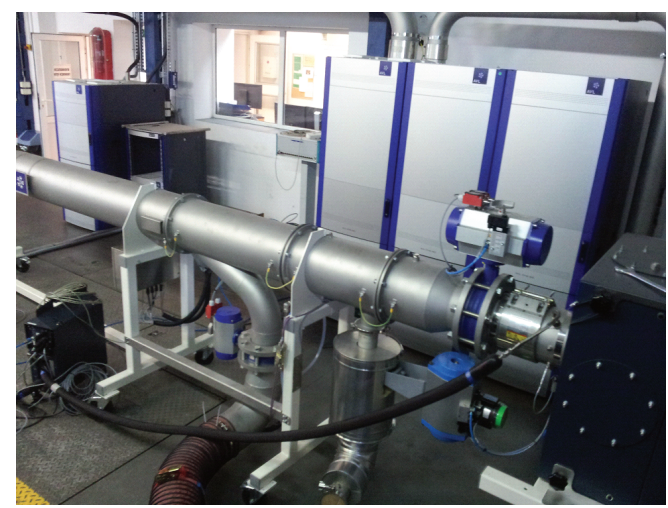

Fig. 2. A set of AMA i60 measuring devices

The Semtech DS analyzer with the GPS module from Sensors Inc. (Fig. 2) was used for measurements and registration of harmful gaseous exhaust gas compounds. It was a PEMS type analyzer that allows measuring the mass flow of exhaust gases and the concentration of harmful compounds such as: carbon dioxide $\left(\mathrm{CO}_{2}\right)$, carbon monoxide (CO), hydrocarbons $(\mathrm{HC})$ and nitrogen oxides $\left(\mathrm{NO}_{\mathrm{x}}\right)$.

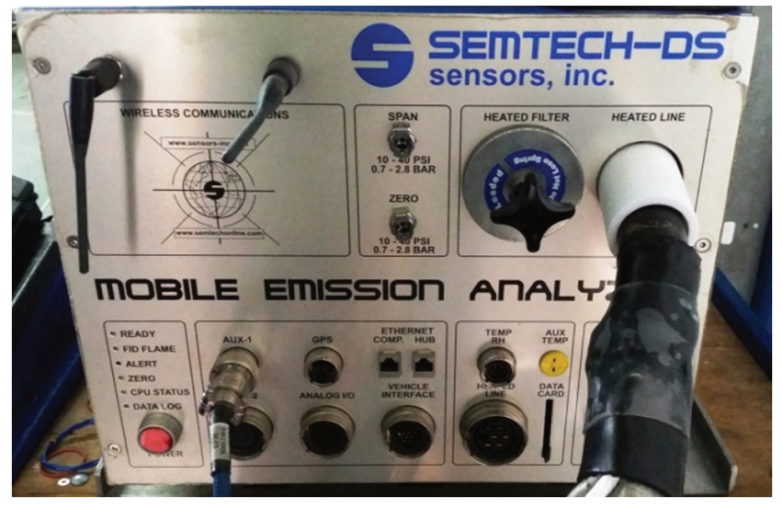

Fig. 3. The SEMTECH DS mobile analyzer used in the Ford Focus Flexifuel vehicle tests

\subsection{Speed registration and mapping}

Figure 3 shows an exemplary fragment of the speed course registered in the real road traffic measurements, while Fig. 4 shows a fragment of the speed course of the discussed artificial test, obtained as a result of treating the input data with a specially prepared calculation algorithm [8]. The obtained test is characterized by a representative level of toxic substances emission and fuel consumption as well as the amount of work done by the vehicle's engine during the test.

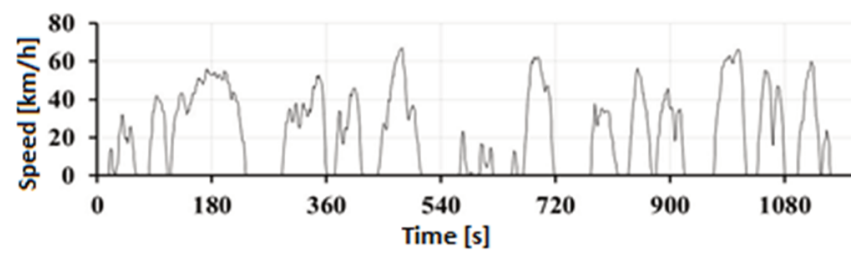

Fig. 4. Selected fragment of the speed course registered in road measurements

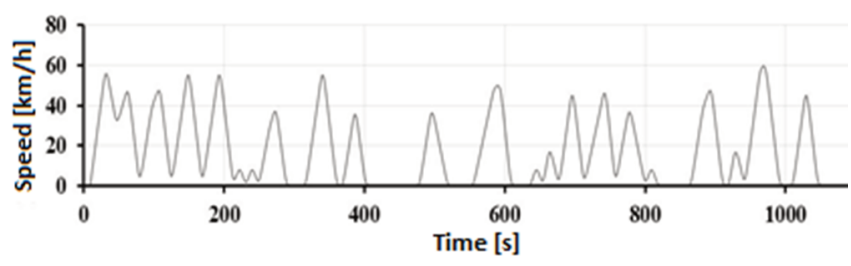

Fig. 5. Selected fragment of the speed course registered in stationary measurements

\section{Findings}

In order to verify the correctness of the assumptions and the correctness of the construction of the based on road measurements stationary test itself, it was necessary to compare the emission values of individual exhaust components. It turned out that the type of measurement equipment used had a significant influence on the obtained results. In the case of hydrocarbons measurement, in road tests the analyzer operating on the principle of using infrared IR built into the mobile measuring device was used, relatively inaccurate in the case of carbon particle emission measurement, due to the registration of the flow of only part of hydrocarbon compounds. However, in the case of laboratory tests, an FID analyzer was used, which shows high accuracy of measurement, recording real and reliable values of carbon emissions. As a result, the recorded road values of the hydrocarbon emission intensity were proportionally lower than the values recorded in the laboratory tests.

Another difference between road and bench tests was the emission intensity values when the engine was idling. They resulted from the method of flue gases flow meter measurement using a Pitot tube, which explains the phenomenon of oscillating emission intensity (also to zero values), because the emission values are the smallest when the vehicle is stationary, and Pitot tube is characterized by the smallest accuracy at small flows $[5,7]$.

Finally, it was decided to use the results of measuring the intensity of carbon dioxide emission as a constituent of exhaust, which best describes the level of representativeness of the designed test relative to road tests. The amount of carbon dioxide emitted is proportional to the amount of fuel consumed in the tests and, as a result, proportional to the work done by the engine.

For a more reliable confirmation of the representativeness and repeatability of the results, the Mann-Whitney statistical significance test was carried out. He showed that at the significance level of 0.05 there are no grounds to reject the hypothesis about the lack of significant differ- 
ences between the results of individual tests [4]. This is the key information that authorizes us to accept the hypothesis about the compatibility and repeatability of the tests performed for the most important exhaust component.

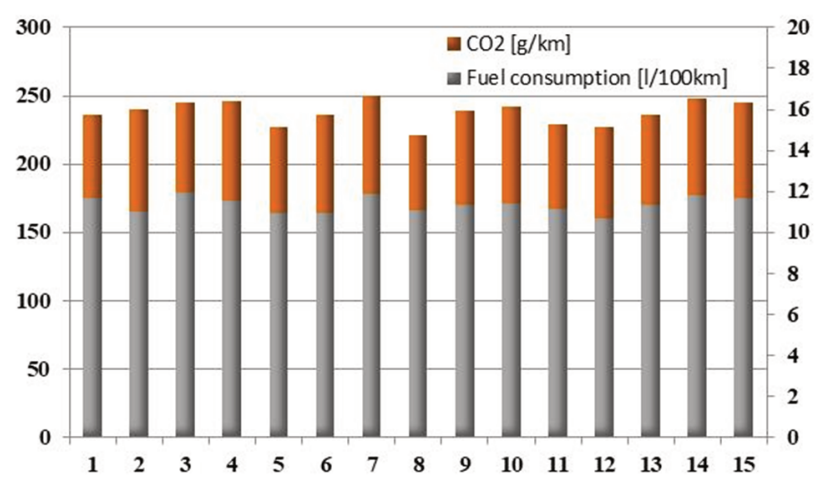

Fig. 6. Fuel consumption and carbon dioxide emissions

In order to more reliably confirm the representativeness of the obtained tests, during the tests mass measurement of fuel consumption was performed during stationary tests both in the designed tests and in the test reproduced directly according to registered vehicle speeds in road ones.

Figure 6 shows the fuel consumption in subsequent tests performed on the chassis dynamometer and the carbon dioxide emission values in these tests. A significant correlation of the obtained results can be observed, which proves the high repeatability of the conducted tests on the chassis dynamometer.

\section{Conclusion}

Based on the analysis of carbon dioxide emissions, there was significant compatibility between road and stationary tests. The results of synthetic tests differed by no more than $2.5 \%$ compared to road tests. They confirm significant correctness of the mapping. Since the discrepancy was much greater for the other components, it can safely be said that of all exhaust components of the exhaust system, carbon dioxide is the best component to determine the comparability of the tests obtained [2].

$\mathrm{N}_{2} \mathrm{O}$ Nitrogen dioxide

NO Nitric oxide

$\mathrm{NO}_{2}$ Nitrogen dioxide

$\mathrm{NO}_{\mathrm{x}}$ Nitrogen oxides

PEMS Portable Emissions Measurement System

THC Hydrocarbons

FID Flame Ionization Detector

IR Infra Red

\section{Bibliography}

[1] MERKISZ, J., RYMANIAK, Ł. Determining the environmental indicators for vehicles of different categories in relation to $\mathrm{CO}_{2}$ emission based on road tests. Combustion Engines. 2017, 170(3), 66-72.

[2] WIŚNIOWSKI, P., ŚLĘZAK, M., NIEWCZAS, A., SZCZEPAŃSKI, T. Method for synthesizing the laboratory exhaust emission test from car engines based on road tests. IOP Conf. Series: Materials Science and Engineering. 2018, 421, 042080. DOI:10.1088/1757-899X/421/4/042080.

[3] KUTRZYK, A., FILIPCZYK, J., Określenie poziomu emisji składników spalin dla różnych warunków pracy silnika. Zeszyty Naukowe Politechniki Ślaskiej. 2008, 64, 167-174.

[4] HYK, W., STOJEK, Z. Analiza statystyczna w laboratorium. 2016, $P W N$, Warszawa.

[5] BIELACZYC, P. O badaniach emisji związków szkodliwych spalin z silników samochodowych w warunkach trakcyjnych metodą RDE (PEMS). Przeglad Techniczny. 201624.

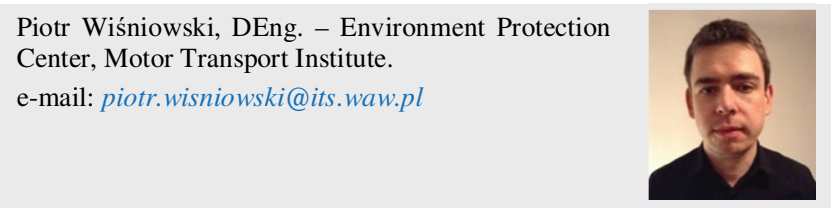

[6] BEBKIEWICZ, K., CHŁOPEK, Z., SZCZEPAŃSKI, K. Estimating pollutant emission from motor vehicles in the years 2000-2015. Combustion Engines. 2017, 171(4), 62-67.

[7] WIŚNIOWSKI, P., ŚLĘZAK, M., NIEWCZAS, A., SZCZEPAŃSKI, T. Dobór metody filtrowania przebiegu prędkości pojazdu. Autobusy: technika, eksploatacja, systemy transportowe. 2017, 9, 24-29.

[8] SZCZEPAŃSKI, T., WIŚNIOWSKI, P. Typowe zadania realizowane przez silnik spalinowy. Transport Samochodowy. 2017, 1, 85-104.

[9] MERKISZ, J., PIELECHA, J., JASIŃSKI, R. Ocena emisji spalin pojazdów kategorii Euro $6 \mathrm{w}$ testach drogowych., Prace Naukowe Politechniki Warszawskiej. 2017, 115, 131-144.

[10] CHŁOPEK, Z. Synteza testów jezdnych zgodnie z kryteriami podobieństwa charakterystyk częstotliwościowych. Eksploatacja i niezawodność - Maintenance and Reliability. 2016, 18(4), 572-577.

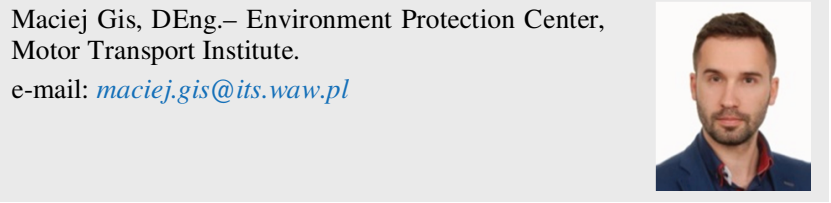

